\title{
Human Resource
}

\section{Management At The Crossroads}

\author{
Narayan Krishna Prabhu, Ph. D., Global Institute for Management Science, Kingdom of Bahrain
}

\begin{abstract}
Getting work done through other people is management; heterogeneities and complexities are managerial issues. Studies in management in $20^{\text {th }}$ and $21^{\text {st }}$ centuries focused on principles of management and management practices. The management theory jungle continues to be dense and impenetrable. Pessimism rules the roast with organizations perceived as insensitive. There is a divide between theory and practice. Epistemology of management practice and management theory building needs to be understood. HRM processes have to be evaluated along with choice making. Theories have to be self fulfilling by changing conditions under which they work. A number of failure stories have been analyzed, impacting several role holders. Searching for evidence for the various failures have provided live instances of actual situations which have caused trauma to the role holders. Financial scandals along with issues of corporate governance have generated conflict. Reviewing practices one perceives repeat errors perpetuated by managers; they are engaged in handling symptoms rather than curative aspects. Grand exits follow. Managers do not consider it safe and seem to work under such constraints. How long will they wait.
\end{abstract}

Keywords: management theory jungle; epistemology of management practice; HRM processes; role holders; financial scandals; corporate governance

...employees are offering a very important part of their life to us. If we don't use their time effectively, we are wasting their lives. [Comment made by Eiji Tayoda, former CEO of Toyota Motor Corporation] (Minuora, 2002).

In the 1940s, Antonnie de Saint - Exupéry wrote:

If you wish to build a ship, don't start looking for wood, cutting tables or begin allocating tasks; what you should do first is, find men with a desire to sail on the wide ocean. [Cited in Gracía Dolan, 1997: xxi].

\section{INTRODUCTION: DEFINING MANAGEMENT}

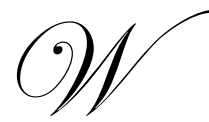

hat is management? "Getting things done through other people" or "coordinating the efforts of people towards common goals". The "other people" involved may be subordinates, clients, customers, suppliers, authorities, or the public in general. Important management is always about people. Jobs (or careers) in which no other people are involved are technical, not management (Hofstede, 1999). Mark Parker Follett has also defined Management as "the art of getting things through people." Considering conservative definitions, "Management is the process of designing and maintaining an environment in which individuals, working together in groups, efficiently accomplish sustained aims (Koontz and Weilrich, 1990, p. 4). On identical lines, Richard L. Daft defines management as the attainment of organizational goals in an effective and efficient manner through planning, organizing, leading, and controlling organizational resources. Management has also been defined by several others as the accomplishment of goals through others. Human beings (or resources) are continually being viewed as the driving force for the success of organizations; because of the sheer skills, competencies, knowledge, expertise and experience (Becker, 1975; Schmidt \& Lines, 2002; Harrison \& Kessels, 2004). In fact managerial skills are specific abilities that result from knowledge, experience, information, practice, and aptitude (Bateman and Snell, 1996). 
Whether management is a profession or a discipline (Squires, 2001: Storey, 1989, 1990)? Coaldrake and Stedman (1999) opines that 'despite frequent use of the term academic profession, academic work is organized and governed in ways that do not reflect what other groups might understand by the term profession 'Complexity in organizations often sends chill down the spine of many role holders heterogeneous customer needs; differing cultural values; a plethora of stakeholders with different claims (investors, customers, employees, regulators etc.): various political, economic and legal environments; and finally, competitors' differing strategies (IMD, 2007). Managing these complexities matters; managers have a herculean task in managing these heterogeneities; the question often asked is 'do they?' or do they just indulge in appeasement process.

Drucker's classic work of the $20^{\text {th }}$ century, Management: Tasks, responsibilities, Practices, emphatically states, 'In this century, society has become a society of organizations. Every major task in this society is being performed in and through large, managed institutions. As a result, the great majority of people in developed countries work as employees. They work as members of managed institutions and within a managerial structure and organization (Drucker, 1973).' Again it is a truism that all management frameworks must fit the environment, mission, people, core competencies, and technologies in which they are implemented. If it does not make sense, it is not right for managing people (Service, 2010). And as we have heard before, 'If it does not fit' - 'you must quit' yourself of the theory (Service and Arnott, 2006)! "Is this all managing?"

\section{STUDIES IN MANAGEMENT}

\section{Some Hopes}

Studies in management, one in the mid twentieth century and two other in the first decade of the twenty first century speak about certain positive aspects of management. Fayol (1949), recognized, principles of management that can be used to enhance organizational performance. Fayol further said "principles are flexible and capable of adaptation to every need; it is a matter of knowing how to make use of them, which is difficult art requiring intelligence, experience, decision and proportion" (1949, p.19). Bloom and Van Reneen (2007), two economists who studied manufacturing firms in US, UK, France and Germany, found that the firm's financial performance was a function of the degree to which they followed "well established management practices" be it in the area of operations, performance management, and talent management. Kramer (2008, p. 26) provides a different flavor concludes (that management) "is a strange mixture of alchemy, romantic idealism and reason."

Harold Koontz (1961) argues in his work, The Management Theory Jungle, that confusion (prevails) among intelligent managers arising from the wide differences among management experts in the field of management. Two decades later Harold Koontz (1980) reiterates in a subsequent work, The Management Theory Jungle Revisited, on a revisit to the jungle (of management), the jungle becomes more dense and impenetrable. To explore and exploit the management jungle the managers are exposed to need-based training and development inputs to provide the vital skills and competencies. Many companies have put their managers through sensitivity training, often referred by opponents of such initiative as "psychological striptease" only to find that the managers had learned much about feelings but little how to manage (Koontz, 1980). The capacity of the managers for formulating and solving complex problems is very small compared with the size of the problems whose solution is required for objectively behavior in the real world as per Simon (1957). The problem of disassociation of espoused theory and the theory of use for the individual manager as described by Argyris and Schön (1978): when someone is asked how he would behave under certain circumstances, the answer he usually gives his espoused theory of action, to which he gives his allegiance and which, upon request he communicates to others. The theory that actually governs his actions in his theory - in - use, which may or may not be compatible with the exposed theory; furthermore, the individual may or may not be aware of the incompatibility.

\section{Pessimism}

Chronologically, there have been a number of studies in management which have set alarm bells and a mood of pessimism. Hamel (2008) argues that the modern study of management is stagnant and out of date. Khurana (2008) argues that attempts to create science of management have failed. However, Hofstede (1999) claims that, 'Management in the $21^{\text {st }}$ Century will not be basically different from the management in the $20^{\text {th }}$ Century, but we can expect a breakthrough in the development of theories of management which will become more adapted to 
national culture value systems in different parts of the world.' Again, Hofstede presents multiple facets; he says popular literature suggests that management processes change over time one should follow latest trends management processes are universal and can be applied across the world. And thereafter he presents; 'I defend the opposite viewpoint: Management processes basically have changed little over time. They differ less from period to period than from part of the world to part of the world, and even from country to country (Hofstede, 1999). There are negative trends as many managers in the $21^{\text {st }}$ Century view organizational missions, visions and values with skepticism (Hemmingway and Maclagan, 2004). Again these managers who have made people redundant too often experience it. They see redundancy as nothing more than the consequence of senior management's self - interest, and they either withdraw from the process and sulk or claim that the choice of whom to make redundant may as well be left to some arbitrary process such as drawing lots (Sanghi, 2002). Managers often experience a very high degree of stress, often resulting in burnout when there is a persistent imbalance of demands over resources (Aiken et al, 2001; Bakker and Demerouti, 2007). It needs to be appreciated that when demands increase more service recipients with more intense requirements - resources fail to keep pace. There are insufficient, personnel, equipment, supplies, or space to meet the demand (Aiken et al, 2002). When managers fail, it costs time and resources to recruit, select, and train new ones; also hidden costs associated with managerial hubris and golden parachutes, lost social and intellectual capital, missed business objectives, decline in employee health and destroyed employee morale(Hogan $e t$ $a l$, 2009). Organizations rarely prepare managers or support them afterwards in their journey of career progression (Freedman, 2005; Watkins. 2003). There have some change in the "Swim - or - sink" mind-sets in recent years with managements opting for increased focus as well as talent retention. Methods for facilitating transitions for capable managers now appear in the practitioner literature based on the real life experiences at American Express, General Electric, Johnson and Johnson, Pitney - Bower, and Wal - Mart (Downey et al., 2001; Volhardt, 2005; Watkins, 2003).

Common management practices in areas like performance appraisals, teamwork, diversity etc. along with experiences of managers indicate that practices and theory are not in agreement with each other. The practice of management is characterized by its ambiguity ... that leaves the managers mostly with the messy stuff - the intractable problems, the complicated connections. And that is what makes the practice of management so fundamentally 'soft' and why labels such as experience, intuition, judgment, and wisdom are commonly used for it (Mintzberg, 2004). Many of the 'chicken managers' take refuge in idiosyncratic terms like 'teamwork' to hide poor performers or the diversity function is mostly window dressing (Service, 2010). Again these very managers are not very good. Half are below average, and average is relatively poor (Service, 2010). Court rulings come every day that can get managers into hot water; sexual harassment, ethics, values, leadership development; psychological disorders such as disabilities, illegal discharge, employment of illegals, and employee piracy are huge (Smith and Mazin, 2004) Sadly people, including managers, are looking for the magic bullet, the key, the secrets, the pill, the luck break (Lobb, Dizik, and Porter, 2009). Success is not a matter of mastering theory, but rather of understanding and embracing common sense variables with uncommon levels of discipline (Lencioni, 2002). When you are dealing with people, an ounce of fact outweighs a pound of theory (Tobin, 2003). Management is common sense and truly it is not common amongst people (managers). Ayan Rand's 1957 Atlas Shrugged, a work of fiction, makes humanist points that can be applied to many managerial situations involving common sense and not performing difficult tasks in a quality manner. One of the characters therein says: "You see people ..., people do not want to think. And deeper they get into trouble, the less they want to think. But by some sort of instinct, they feel that they ought to and it makes them feel guilty. So they'll bless and follow anyone who gives them a justification for not thinking (Rand, 1957). Clearly the lazy among us (people - managers [italics]) \{most of us - 'people - managers' for that matter want permission not to think but to blindly follow theories and pronouncements (Dorner, 1996).

Again, the study of business as definable theories and discipline began in the discipline of economic theory. The three basic assumptions that guide economic theory are: 1) markets are free: 2) people's action are rational; 3) participants have perfect and equal information (Friedman, 2005b; Gladewell, 2008; and Levitt and Dubner, 2005). If one were to examine do these assumptions hold true; the response would be that there are exceptions to these basic rules of economics. It is being seen that - markets are not totally free anywhere in the world, human never act absolutely rationally, and no one has complete and perfect information. The ideas of economists and political philosophers, both when they are right and when they are wrong, are more powerful than is commonly understood (Keynes, 1936: 383). 
Epistemology of practice of management will reflect a concern for principles of contextualism (Mahoney \& Sanchez, 2004). Contextualism requires that there is a context - dependent gap between universal management theory and concepts useful in a specific context (i.e. useful to a specific manager, at a specific time on a specific issue [Barnes, Christensen, \& Hansen, 1994, p.47]). Management theory building must necessarily include factors that are responsible for observed patterns in specific management contexts (Burgelman, 1983; Leonard-Barton, 1995; Mintzberg, 1973; Penrose, 1959). This central importance of context is emphasized by Hicks (1976). Since it is a changing world that we are studying, a theory that illuminates the right things now may illumine the wrong things another time. This may happen because of changes in the world (the things neglected may have grown relative to the things considered) or because of changes in the source of information (the sort of facts that are readily accessible to us may have changed) or because of changes in ourselves (the thing in which we are most interested may have changed) (Hicks, 1976, p.208).

There are urgent needs expressed, for example to evaluate Human Resource Management processes in terms of organizational impact (Huselid, 1995; Schuler, 1998) clearly the perception by HR professionals as the need to evaluate is very welcome, given the sequence of unevaluated management fads, latest fads, regardless of theory or evidence. These stereotypes have received support from academicians practiced in organizations over the last two decades (Neil Anderson, et al, 2001). An organization or manager may get quick returns, if he takes short cuts, climbs over others' shoulders or puts down his competition - but in the long run of professional life, he is inevitably left behind (Khwuja, 2010). The manager has choices to make.

Every management text (Hamel \& Prahalad, 1994) recounts the litany of changes in the business environment that profoundly affect organizations and the people who work within them. Globalization, competition, deregulation and technological change combine to make organizational survival more dependent upon the skills and motivation of employees (Cascio, 1995; Cooper \& Jackson, 1997; Herriot \& Anderson, 1997; Hodgkinson \& Herriot, in press). How to engage employees in an employment relationship that enhances their contribution and the organization's performance has to become one of the most urgent problems facing clients (Herriot, 2001).

Theories can become self-fulfilling when institutional designs and organizational arrangements-structures reward systems, measurement practices, selection processes reflect the explicit or implicit theories of their designers, in the process of transforming "image into realities" (Miller, 1999: 1053; Frank, 1988) by changing material organizational conditions and practices. Schwartz (1997:22) noted that Skinnerian views about reinforcement (Skinner, 1953) might be true not because of some essential characteristics of human nature but because "the more these institutions (human work places-offices, schools, mental hospitals) were structured in keeping with Skinner's theory, the more true the theory would look not, the more true the theory would be." Managing people through contingent reinforcement could, over time, "change people's motives to engage in the task and the manner in which tasks are performed" (Schwartz, 1997: 22) in ways consistent with principles of reinforcement.

\section{FAILURE STUDIES}

Bentz (1967, 1985a, 1985b, 1990) studied causes of managerial failure for about three decades; Bentz (1985a) noted that a certain section of managers in the retail industry who were uniformly bright and socially skilled failed because of the following reasons: (1) lacked business skills, (2) were unable to deal with complexity, (3) were reactive and tactical, (4) were unable to delegate, (5) were unable to build a team, (6) were unable to maintain relationships with a network of contacts, (7) let emotions cloud their judgment, and (8) were seen as having "overriding personality defect." The reference to personality defect in fact lies in the definition of leadership 'ability to build as well as maintain a team that can tackle competition' (Hogan, 2007, pp. 34 - 35). In another study of both men and women managers, conducted by Morrison, White, and VenVelsor (1987) using the McCall and Lombard's (1983) methodology, found the problems with managers appalling: (i) Unable to adapt to a new boss, (ii) Performance problems, (iii) Too ambitious, (iv) Can't manage subordinates, (v) Poor relationships, (vi) Not strategic, and (vii) having a poor image. MaCauley \& Lombardo (1990) conducted a survey to measure the managerial behaviors associated with failure: (a) Problems with interpersonal relationships, (b) difficulty in molding a staff, (c) Difficulty in making strategic transitions, (d) lack of follow - through, and (f) strategic difference with management. Another quantitative study, (using 360 degrees appraisal/ feedback or full circle assessment) was conducted by Eichinger and Lombardo (2003) as to why managers are fired: (A) poor administrative skills, (B) Difficulty making tough choices, (C) Lack of strategic thinking, (D) Failure to build a team, (E) Lack of 
interpersonal savvy, (F) Poor political skills, (G) An inability to deal with conflict, (H) Questionable integrity, and (I) Low self - awareness. In review of business failures, Finkelstein (2003) has observed seven habits of spectacularly unsuccessful people ('managers') (p. 238): (1) They overestimate their strength and underestimate the strength of the competition [ a la Managerial 'hubris'], (2) They put personal interests ahead of company's interests, (3) They are arrogant and make reckless decisions, (4) They eliminate anyone who challenge their decisions, (5) They ignore operations while trying to manage the company's image, (6) They minimize difficult obstacles and don't plan accordingly, and (7) They rely on outdated strategies and tactics. Certain other studies have established that managerial failure is often not on account of strategy and tactics, but more so on account of poor execution (Bossidy \& Charan, 2002; Charan \& Colvin, 1999). Charan proceeds to define poor execution as "not getting things done, being indecisive, not delivering on commitments." Bossidy and Charan (2002) list four causes of poor execution: (A) The managers not understanding their own business and the capability of their staff, (B) Not using (following) sound management practices; setting clear goals; following up; good performance; and good talent, (C) Culture does not encourage Value - execution, and (D) not putting the right people on the right job ["square pegs in round holes"]. In a subsequent study, Rasch, Shen, Davies, and Bono (2008) offer taxonomy of ineffective leadership behavior; nine empirically derived behaviors: Avoiding conflict and people problems; Poor emotional control; Over - controlling; Poor task performance; Poor planning, organization and/ or communication; Rumor mongering and inappropriate use of information; Procrastination; Failure to consider human needs; and Failure to manage and nurture talent. Dotlich and Cairo (2003) list ten characteristics associated with CEO failure: (a) arrogance; (b) melodrama; (c) excessive caution; (d) habitual distrust; (e) aloofness; (f) mischievousness; (g) eccentricity; (h) passive resistance; (i) perfectionism; and (j) eagerness to please. Everyone has some of these tendencies, CEOs are more vulnerable, because of the pressure of being on the top of the pyramid, self-awareness can mitigate the influence of these tendencies on organizational effectiveness. Thus organizations do face many teething problems, some of these hover around the lack of so-called qualified and competent human beings especially in a global context and this is seen as a hindrance to effective management (Roberts and McDonald, 1975; Fernald et al, 1999; Shim, 2001; Lloyd, 2002; Budhwar et al, 2002; Bates et al, 2002).

\section{Failures: Panacea}

Recent past has witnessed scores of corporate failures all over the world. The subprime crisis in the United States of America has shaken the economic fundamentals of many a developed and developing countries across the globe. The crisis has set in motion recession and depression of a kind worse than what was experienced in 1930s ['when America sneezed on account of economic crisis then the World caught pneumonia'] during the Great Depression Era. Misguided corporate objectives, lack of integrity and righteousness of the management and other statutory bodies of corporate organizations have played a major role in the corporate and economic debacles. In such a socio - economic - politico milieu, it is time to do soul searching and look for a more sustainable approach to management. Management professionals need to be trained to become responsible corporate citizens who through their profession will play a constructive role in societal development by ensuring the welfare of all the organizational stakeholders in the process of organizational decision making. "What is the panacea for financial and other such organizational problems in the world?" There are no readymade, instant, everlasting solutions. (Bhaskar, 2009). Collapse of giant corporates is not only a source of great confusion but also a matter of major concern. We have learnt to our dismay that legal requirements, institutional checks and balances, and corporate governance systems are no longer able to avert, control or mitigate the undesirable outcomes while shareholders and employees continue to be major casualties. The matter does not rest there. It is indeed the body of all stakeholders - promoters, corporate board members, shareholders, suppliers, financial institutions, employees and customers who have to go through agonizing experiences in different ways and with differing intensities. At a deeper level, the societal consciousness itself is deeply scarred though it may not always be properly perceived as such. One does not have to work too hard to realize that in one way or the other the root of the problem lies in unscrupulous, myopic and mistakenly self-centered behavior of persons holding important positions. Most corporate debacles can be understood this way with very few exceptions (Pandit, 2009). It is often reported that a few covetous and unprincipled people are behind such corporate debacles Enron, World Telecom, Leman Brothers, Satyam InfoTech of India etc. (Rao, 2009). Was the U. S. Subprime incident a "Black Swan," an unforeseeable event? In fact many analysts gave early warnings about US housing bubble burst and a number of firms positioned themselves to profit from the risk. Robert Schiller: "There was a failure to communicate and a failure to put all this information together and act on it in a systematic way." Source: portfolio.com, "world according to Robert Schiller, "by Lloyd Grove. 
Richard Fuld's Lehman illustrates the dangers of autocratic leadership and Group Think - Fuld's autocratic leadership squashed dissenting viewpoints - Fuld was known around the office as "the Gorilla." His icy stare, people who worked at Lehman say, froze recipients with fear. No one wanted to tell Fuld something was wrong or questioned how Lehman was run ... Fuld pushed potential rivals aside. Fuld appointed Gregory as Chief Operating Officer (COO), a trusted lieutenant who had worked at Lehman since 1974. He would make it a mission to keep Fuld's life uncomplicated by debate. Any meeting with Gregory was a soliloquy. The COO delivered lectures on matters as minute as improving the look of sloppy dressers. Management - Committee meetings were conducted without discussions. The same was true of executive committee meetings presided over by Fuld. While reviewing budgets for 2007, one committee member questioned the performance of a unit, according to a person who was in the room. Fuld stared at him coldly, then broke the silence: "You've got some balls to say that, knowing how much I hate that topic." As Fuld returned to studying the papers in front of him, Gregory continued dressing down the committee for his impertinence. He also upbraided him after the meeting, demanding that any objections be brought to Gregory privately and not voiced in front of the committee. Source: Bloomberg, Onaran \& Helyar, "Fuld Sought Buffett Offer He Refused as Lehman Sank.”

Merrill's Missed Opportunity For Risk Management - Merrill's Silos \& Stan O'Neal - Risk was not integrated but split between a credit risk officer and a market risk officer both of whom reported to the CFO, who then reported to the CEO contradicting then - CEO Stan O'Neal was a dangerous game. "Either you did what he

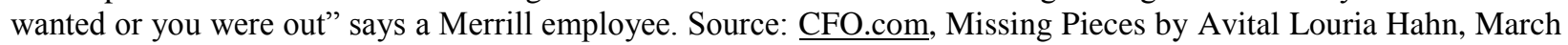
2008.

Thain clearly believes that his predecessor emphasized the wrong Goldman virtues. Sure, Goldman engages in high stake bets, but it is organized in a way that places maximum emphasis on risk management. O'Neal left out that part. So Thain's Goldmanizing of Merrill has a different flavor: He is removing the silos of the past, dismantling hierarchies and cliques that kept departments isolated from one another. His revamping of the compensation system is also the Goldman way, a sharp departure from O'Neal's "everyman for himself" pay structure. Source: portfolio.com, The Taming of Merrill Lynch by Gary Weiss, May 2008.

\section{SCANDALS \& DILEMMAS}

Massive financial scandals and issues of corporate governance have garnered so much attention over a period of time. A reorientation of management as a subject matter, rather than just 'managing the show' should obviously permit senior managers [role holders] to harness the innate talent to provide critical, analytic thought and analysis on the role of the corporation and the place of management and other organizations in the society. It is reiterated that Corporations fulfill needs of shareholder as well as other people (Basu, 1999; Senge, 2000; Kelly, 2001; Mitchell, 2001; Handy, 2002; Emiliani, 2003a, Tsurumi, 2005). However, in many writings, based on mind capturing assumptions, the entire case is presented as an 'either - or - proposition' (Friedman, 1970a; Jensen and Meckling, 1976; Jensen, 2000). Managers have misread and misjudged the logic; addendum it has created tentativeness, uncertainty and confusion in the business captains and stakeholders as well (Allen, 1992; Begley, 2005; Ferrao et al., 2005; Ghosal, 2005; Grow, 2005; Witzel, 2005; Tsurumi, 2005). This creates a conflict different motives and accompanying behaviors between company owners and managers; there being no resolution (Jensen and Meckling, 1976; Jensen, 2000). Thus we have a situation where social consequences as well as social dimensions of businesses are ignored. Managements must be more interested in developing, promulgating and enforcing ethical standards of conduct 'Repurposing'. Managers tend to have a run - of - the - mill approach; for instance, managerial response to competition is to copy their competitors. Again managers build their 'ivory tower' organizations by gathering information from others that have succeeded in benchmarking; they also palm - of the information to other organizations claiming that the information as theirs. Resting on the historical relics of other organizations does not constitute an effective management strategy.

\section{Practices}

In practice of management one can see a combination of science, arts and crafts; it is possible to teach the science of management to willing participants; however it is more difficult to inculcate and absorb the arts or crafts related sound judgment, creative inspiration as well as entrepreneurial innovation (Holian, 2004). Middle level 
managers in particular start experiencing plateauing in their managerial performance, (mid-career blues!), more so on account of personal qualities and/ or personal preferences; assessment of the same could be done by Myers Briggs Type Indicator (MBTI) (Briggs - Myers and Myers, 1990; Myers and McCaulley, 1990) or even (Belbin's) team roles; these assessments may be correlated with the choice of these personnel to take up managerial position, along with the perceived as well as the actual performance in their roles.

It is observed in organizations that strategic and tactical errors are common in business and typically repetitive in nature (Emiliani, 2006); the causes being ... faulty internal communication, incorrect theories or assumptions about business, and incorrect application of new methodologies such as six - sigma (Finkelstein, 2003; Ferraro et al, 2005; Ghoshal, 2005; Tsurumi, 2005; White, 2005). Managers continue to perpetuate the same errors although they may move from one organization to another; this results in colossal personal and business expense. In a typical; problem solving process managers are found to be wanting in problem recognition, identification of the root cause(s) and taking preventive interventions to stall the recurrence; their plight can be perceived in 'current state value stream maps' (Rother and Shook, 1999; Emiliani and Stec, 2004). Again managers are seen prepared to handle symptoms rather than curative aspects thus resulting in wastage of valuable resources; thus in a typical cause - and - effect dynamic managers are seen focusing on the effect aspect. Thus if senior role holders in an organization do not think that the study of the root cause is important than the role holders down the line would care about it. In fact the tools like '5 Whys' (Ohno, 1988), 'cause - and - effect' OR 'fishbone' should help in root cause analysis. Alas, being in an activity trap managers do not have time for the same. The top leadership too do not want to hold the bull by the horns; they prefer to hide errors and blame other people for the same (Emiliani, 2006). This entails into organizational politics to obfuscate (Argyris, 1990) - instead of providing value based products and services to the customers. We often see subprime management more often than not. We come across leaders ('managers') who don't know how to manage in the most important positions (Drucker, 2001; Wren and Bedeian, 2009).

\section{'UNHOLY' EXITS}

Good people leave organizations because: 1) They see no link between pay and performance. 2) They do not perceive growth or advancement opportunities. 3) They do not see their work as important; or their contributions are not recognized. 4) They do not get to use their talents. 5). They have unclear or unrealistic expectations. 6) They will no longer tolerate abusive managers or toxic environments (Service and Lockamy, 2008); a la 'shape - up' or 'ship - out'. A number of studies have shown that most managers are not very good, half are below average, and the average is relatively poor. The social fabric in many work places mandatorily requires people to be away from their homes on office chores. People spend more time at work (Schur, 1991) most of the waking time is sucked into work related processes, with no personal or private time triggering off a lot of psycho - somatic ailments; work, incidentally, becomes an important source of social identity, who one works with and, more importantly, the nature of those social relations in the work place loom, ever important. Mirvis (1997: 198) has noted, "lacking continuity and connection in so many other settings, many naturally look at the organization as a communal canter." The writing on the wall is ever clear to the people characterized by "fear, pressure and impermance" (Mirvis, 1997: 198). Many people continue working in those unsecure places where there are deep psychological scars. Cerner Corporation, an health care development company with Neil Paterson as its CEO is a startling pointer in this direction. He sent email to the employees that they weren't working hard enough (evidenced by empty parking lots during early mornings, late evenings as well as week - ends). He threatened to enforce punitive measures like lay offs, denial of customary benefits as well as other pecuniary as well as non - pecuniary denials if they don't shape up (Wong, 2001); pat also came the deadline: Just two calendar weeks, tick - tock (Wong, 2001). This is just one case, there are many companies that manage through duress, fear and stress (Pfeffer and Sulton, 2000). It is generally known that some 'committed executives' to curry favor for the 'big boss' show their faces on weekends decked in colorful t-shirts and flamboyant jeans; only to disappear when the boss leaves the office. Then there are waves of downsizing (Cappelli, 1999) to bolster the organization; however the question is whether it really benefits the organization? The organization studied showed that those with lower reputations went for downsizing (Ahmadjian and Robinson, 2001), and there were no benefits as such. What is seen is an increased turnover, more people working as temporaries or contractors (Pfeffer and Baron, 1988), under the alibi that organizations must concentrate in the areas of their core competencies. There are also frequent changes taking place in the ownership 'top management', which in turn has reduced the commitment (and loyalty) of the people and have also made them 
reactive and angrier to the erratic changes (Pfeffer, 2001). These managers have been treated unfairly (Folger, 1993), triggering a negative approach (Adams, 1965; Pillutla \& Murnighan, 1996), experience anger as an emotion (Averill, 1982; Frijda, 1986); they are seen to have a perception of injustice, inequity, and dissatisfaction (Fitness, 2000), which is often explicitly expressed. Anger is seen as a signal indicating that deeply held societal or human values are being violated (Goldman, Slaughter, Schmit, Wiley, Brooks, 2008). There is thus a continuing flux in the management world and as the Chinese Proverb goes: níng wéi tàipíng quăn, bù zuò luànshì rén [It is better to be a dog in a peaceful time than be a man in a chaotic period]. The embodiment as a human being though superior amongst the 840, 000 species in the creation does not guarantee a peaceful passage in organizations and in management. It is reiterated that there is no dearth of qualified and experienced managers, scientists, technologists or even administrators; yet there are not available to manage the show of business. How long will the human beings wait?

\section{AUTHOR INFORMATION}

Narayan Krishna Prabhu is currently Dean Academics and Institute Director of Global Institute for Management Science, Kingdom of Bahrain as head of Academics, Research and Consulting for the last 18 months. Prior to this assignment Dr. Prabhu had been associated with several universities, organizations of repute and has held positions in Academics, Industry and Government for the last 35 years. He holds qualifications in management, science, commerce and law. Again, widely travelled, he has presented research papers and training workshops in several countries. His writing focuses on human values along with concomitant societal implications. E-mail: narayankprabhu1953@gmail.com

\section{REFERENCES}

1. Adams, J. S. (1965). Inequity in social exchange. In L. Berkowitz (Ed.), Advances in experimental social psychology: pp. 267 - 299. New York: Academic Press.

2. Ahmadjian, C. L., \& Robinson P. (2001). Safety in numbers: Downsizing and the deinstitutionalization of permanent employment in Japan, Administrative Science Quarterly, 46; pp. 622 - 654.

3. Aiken, L. H., Clarke, S. P., Sloane, D. M., Sochalski, J.A., and Siber, J. H. (2002). Hospital nurse staffing and patient mortality, nurse burnout, and job dissatisfaction, Journal of American Medical Association, 288, pp. $1987-93$.

4. $\quad$ Aiken, L. H., Clarke, S. P., Sloane, D. M., Sochalski, J.A., Busse, R., Clarke, H., Giovannetti, P., Hunt, J., Rafferty, A. M., and Shamian, J. (2001). Nurses report on Hospital care in five countries the ways in which nurses' work is structured have left nurses among the least satisfied workers, and the problem is getting worse, Health Affairs, 20, pp. 43 - 53.

5. Anderson, Neil, Herriot, Peter, and Hodgkinson, Gerard, P. (2001). The practitioner-researcher divide in Industrial, Work and Organizational (IWO) Psychology: Where are we now, and where do we go from here? Journal of Occupational and Organizational Psychology, 74, pp. 391 -411. Printed in Great Britain, The British Psychological Society.

6. Allen, W. (1992). "Our Schizophrenic conception of the business corporation", Cardozo Law Review, 14 (2), pp. $621-81$.

7. Argyris, C. (1990). Overcoming Organizational Defences, Allyn and Bacon, Boston, MA.

8. Argyris, C. \& Schön, D. A. (1978). Organizational Learning: A theory of action perspective, Reading, M A: Addision - Wesley.

9. Averill, J. R. (1982). Anger and aggression: An essay on emotion, New York: Springer - Verlag.

10. Bakker, A. B., and Demerouti, E. (2007). The job demands resources model; state-of-the-art, Journal of Managerial Psychology, 22, pp. $39-28$.

11. Bates, R., Chen, H. C., Hatcher, T. (2002). Value priorities of HRD scholars and practitioners, International Journal of Training and Development, 6(4), pp. 229 - 239.

12. Bateman, T. S. and Snell, S. A. (1996). Management: Building Competitive Advantage. Third Edition, Chicago: Irwin.

13. Barnes, L. B., Chrristensen, C. R., \& Hansen, A. B. (1994). Teaching and the case study method, Boston: Harvard Business School Press. 
14. Basu, S. (1999). Corporate Purpose: Why it matters More than Strategy, Garland Publishing, New York, N.Y.

15. Becker, G. S. (1975). Human Capital: A theoretical and empirical analysis, with reference to education $\left(2^{\text {nd }}\right.$ Ed.). National Bureau of Economic Research, New York: Columbia University Press.

16. Begley, S. (2005). People believe a 'fact' that fits their views even if it's clearly false, The Wall Street Journal, February 4.

17. Belbin, M. (1993). Team Roles at Work, Butterworth - Heinemann, Oxford.

18. Bentz, V. J. (1967). The Sears experience in the investigation, description, and prediction of executive behavior. In F. R. Wickert \& D. E. McFarlands (Eds.), Measuring executive effectiveness, (pp. 147 - 206), New York: Appleton - Century - Crofts.

19. Bentz, V. J. (1985a, August). A view from the top: A thirty-year perspective on research devoted to discovery, description, and prediction of executive behavior, Paper presented at the $93^{\text {rd }}$ Annual Convention of the American Psychological Association, Los Angeles.

20. Bentz, V. J. (1985b). Research findings from personality assessment of executives, In J. H. Bernardin \& D. A. Brown (Eds.), Personality in organizations, (pp. 82 -144). New York: Praeger.

21. Bentz, V. J. (1990). Contextual issues in predicting high - level leadership performance. In K. E. Clark \& M. B. Clarks (Eds.), Measures of leadership, (pp. 131 -144), West Orange, N J: Leadership Library of America.

22. Bhaskar, R. Kumar. (2009). Man Management: A Values Based Management Perspective - Based on the Discourses of Bhagavan Sri Sathya Sai Baba, School of Business Management, Accounting and Finance, Sri Sathya Sai University, Sri Sathya Sai Vidyagiri, Prasanthi Nilayam 515134, Anantapur District, Andhra Pradesh.

23. Bloom, N., \& Van Reenen, J. (2007). Measuring and explaining management practices across firms and countries, Quarterly Journal of Economics, 22, pp. 1341 - 1408.

24. Bossidy, L. \&Charan, R. (2002), Execution, The discipline of getting things done, New York: Crown Business.

25. Briggs - Myers, I. and Myers, P. (1990). Gifts Differing, Consulting Psychologists Press, Palo Alto, CA.

26. Budhwar, P. S., Al - Yahmadi, S. and Debrah, Y. (2002). Human resource development in the Sultanate of Oman. International Journal of Training and Development, 6(3), pp. 198.

27. Burgelman, R. (1983). A process model of internal corporate venturing in a major diversified firm, Administrative Science Quarterly, 28, pp. 233 - 244.

28. Cascio, W. F. (1995). Whither industrial and organizational psychology in a changing world of work? American Psychologist, 50, (11), pp. 928 - 939.

29. Cappelli, P. (1999). The New Deal at Work, Boston: Harvard Business School Press.

30. Charin, R. \& Colvin, G. (1999). Why CEOs fail, Fortune, June 21, pp. 69 - 82.

31. Chinese Proverb. (n.d.). Cited in Ward, David Kick Start your Organization Out of the Crisis: Think like a Start up! Ward Management Consultants.

32. Coaldrake, P. and Stedman, L. (1999). Academic Work in the Twenty-first Century, Occasional Paper Series, 99 H, Higher Education Division, Department of Education, Training and Youth Affairs, Commonwealth of Australia, Canberra, p.10.

33. Cooper, C. L., \& Jackson, S. E. (1997). Introduction, In C. L. Cooper \& S. E. Jackson (Ed.). Creating tomorrow's organizations: A handbook for future research in organizational behavior, UK: Wiley.

34. Dotlich, D. L., \& Cairo, P. C. (2003). Why CEOs fail? San Francisco: Jossey - Bass.

35. Dorner, D. (1996 translation). The Logic of FAILURE: Why Things Go Wrong and What We Can Do to Make Them Right. New York: Henry Holt and Company. Translated from 1989 German Version.

36. Downey, D., March, T., \& Berkman, A. (2001). Assimilating new leaders, New York: AMACOM.

37. Drucker, P. F. (1973). Management: Tasks, Responsibilities, Practices. New York: Harper \& Roe.

38. Drucker, P. F. (2001). The Essential Drucker. New York: Harper Collins Publishers.

39. Eichinger, R. W. \& Lombardo, N. M., (2003). Knowledge summary series: 360 - degree assessment, Human Resource Planning, 26, pp. $34-44$.

40. Emiliani, M. L. (2003a). The inevitability of conflict between buyers and sellers. Supply Chain Management: An International Journal, 8 (2), pp. 107 - 15.

41. Emiliani, M. L. (2006). Improving Management Education, Quality assurance in Education, 14 (2), pp. 363 - 384; Available at www.emeraldinsight.com/0968-4883.htm. 
42. Emiliani, M. L. and Stec, D. (2004), Using value stream maps to improve leadership, Leadership \& Organizational Development Journal, 25 (8), pp. 622 - 45.

43. Fayol, H. (1949). General and Industrial Management, Pitman Publishing, London.

44. Fernald Jr., L. Solomon, G., and Bradley, D. (1999). Small business training and development in the United States. Journal of Small Business and Enterprise Development, 6(4): pp. 310 - 325

45. Ferraro, F., Pfeffer, J. and Sutton, R. (2005). Economics language and assumptions: how theories can be self -fulfilling, Academy of Management Review, 30 (1), pp. 8 - 24.

46. Finkelstein, S. M., (2003). Why Smart Executives Fail: And What You Can Learn from their Mistakes, Portfolio, New York.

47. Fitness, J. (2000). Anger in the workplace: An emotion script approach to anger episodes between workers and their superiors, co - workers, and subordinates. Journal of Organizational Behavior, 21: pp. 147 - 162.

48. Folger, R. (1993). Reactions to mistreatment at work. In J. K. Murnighan (Ed.), Social psychology in organizations: Advances in theory and research: pp. 161 - 183, Englewood Cliffs, N J: Prentice - Hall.

49. Frank, R. H. (1988). Passions within reasons: the strategic role of emotions. ( $1^{\text {st }}$ edn). New York: Norton.

50. Freedman, A., (2005). Swimming upstream: The challenge of managerial promotions, In R. B. Kaiser (Ed.), Filling the leadership pipeline (pp. 25 -44). Greensboro, NC: Centre for Creative Leadership.

51. Friedman, M. (1970a). The social responsibility of business is to increase its profits, The New York Times Magazine, September.

52. Friedman, T. L. (1970b). The world is Flat: A Brief History of the Twenty - First Century. New York: Farrar, Straus and Giroux.

53. Ghoshal, S. (2005). Bad management theories are destroying good management practices, Academy of Management Learning and Education, 4 (1), pp. 75 - 91.

54. Gladewell, M. (2008). Outliers: The story of Success. New York: Little, Brown and Company.

55. Goldman, B. M., Slaughter, J. E., Schmit, M. J., Wiley, J. W., \& Brooks, S. M. (2008). Perceptions of discrimination: a multiple needs model perspective. Journal of Management, 34: pp. 952 - 977

56. Gracía, S., Dolan, S. L. (1997). La dirección par volres, McGraw Hill (Spain).

57. Grow, B. (2005). The debate for doing good, Business Week, August 15, pp. $76-8$.

58. Hamel, G. (2008). The future of Management, Cambridge: Harvard University Press.

59. Hamel, G., \& C. K. Prahalad, C. K. (1994). Competing for the future, Boston, MA: Harvard Business School Press.

60. Handy, C. (2002). What's a business for? Harvard Business Review, 80 (12), pp. 49 - 55.

61. Harrison, R. and Kessels, J. (2004). Human Resource Development in a Knowledge Economy: An Organizational View. New York: Palgrave MacMillan.

62. Hemmingway, C. A. and Maclagam, P. W. (2004). Managers' personal values as drivers of Corporate Social Responsibility, Journal of Business Ethics, 50, pp. 33 - 44.

63. Herriot, P. (2001). The employment relationship: A psychological perspective, London: Routledge.

64. Herriot, P., \& Anderson, N. (1997). Selecting the change: How will personnel and selection psychology survive? In N. Anderson \& P. Herriot (Eds.), International Handbook of Selection and Assessment, Chichester, UK: Wiley.

65. Hicks, J. (1976). Revolutions, In S. Latis (Ed.), Method and appraisal in economics, pp. 207 - 218, UK: Cambridge University Press.

66. Hodgkinson, G. P., \& P. Herriot, P. (in press). The role of psychologists in enhancing organizational effectiveness, In I. Robertson, M. Callinan, \& D. Bartram (Eds.), Organizational Effectiveness: The Role of Psychology, Chichester, UK: Wiley.

67. Hofstede, Geert (1999). Problems Remain, But Theories Will Change: The Universal and the Specific in the $21^{\text {st }}$ - Century Global Management, Organizational Dynamics, Summer 99, 28 (1), p34 11p.

68. Hogan, R. (2007). Personality and the fate of the organizations, Hillsdale, Erlbaum, NJ.

69. Hogan, J., Hogan, R., \& Kaiser, R. (2009). Management Derailment: Personality Assessment and Mitigation, Hogan Assessment Systems - The Science of Personality, To appear as a Chapter in American Psychological Association Handbook of Industrial and Organizational Psychology, Washington.

70. Holian, Rosalie. (2004). The practice of management education in Australian universities, Management Decision, 40 (3, 4), pp. $395-405$.

71. Huselid, M. A. (1995). The impact of Human Resource Management practices on turnover, productivity, and corporate financial performance, Academy of Management Journal, 38, pp. 635 - 672. 
72. IMD, (2007). Perspectives for Managers, IMD, P. O. Box 915, CH 1001, Lausanne, Switzerland, No. 141, Feb 2007; Available at http://www.imd.ch.

73. Jensen, M. (2000). Value maximization and the corporate objective function, in Beer, M. and Nohira, N. (Eds.), Breaking the Code of Change, Harvard Business School Press, Boston, MA, pp. 37 - 57.

74. Jensen, M. and Meckling, W. (1976). Theory of the firm: managerial behavior, agency costs, and ownership structure, Journal of Financial Economics, 3 (4), pp. 305 - 60.

75. Kelley, M. (2001). The Divine Right of Capital, Barett - Koehler Publishers, Inc., San Francisco, CA.

76. Keynes, J. M. (1936), The General Theory of Employment, Interest and Money, Macmillan, Cambridge University Press [For Royal Economic Society in 1936].

77. Khurana, R. (2008). From hired aims to hired hands, Cambridge: Harvard University Press.

78. Khwuja, Ali (2010). Why should one indulge in Ethical Management? Asian Journal for Professional Ethics \& Management, January - March 2010, 1 (4).

79. Koontz Harold. (1961). The Management Theory Jungle, Academy of Management Review, 1961, 4 (3), pp. 174 - 188 .

80. Koontz Harold. (1980). The Management Theory Jungle Revisited, Academy of Management Review, 1980,5 (2), pp. $175-187$.

81. Koontz, Harold, and Weilrich, Heinz. (1990). Essentials of Management, Fifth Edition, McGraw Hill, p .4.

82. Kramer, R. J. (2008, June). Have we learned anything about leadership development? Conference Board Review, 45, pp. $26-30$.

83. Lencioni, P. (2002). The Five Dysfunctions of a Team. San Francisco: Jossey - Bass.

84. Leonard - Barton, D. (1995). Wellsprings of knowledge: building and sustaining the resources of innovation, Boston: Harvard Business School Press.

85. Levitt, S. D. and Dubner, S. J. (2005). Freaknomics. New York: William Morrow.

86. Llyod, C. (2002). Training and development deficiencies in "high Skill" sectors. Human Resource Development Journal, 12 (2), pp. $64-81$.

87. Lobb, A., Dizik, A. and Porter, J. (2009). Lesson that fits the Times, The Wall Street Journal, August 20: B5.

88. McCall, M. W. Jr. \& Lombardo, M. N. (1983). Off the track: why and how successful executives get derailed, Technical Report No. 21, Greensboro, N C: Centre for Creative Leadership.

89. McCauley, C.D., \& Lombardo, M. M. (1990). Benchmarks: An instrument for diagnosing managerial strengths and weaknesses. In K. E. Clark \& M. B. Clark (Eds.), Measures of Leadership, (pp. 535 - 545). Greensboro, N. C.: Centre for Creative Leadership.

90. Mahoney, J. T. \& Sanchez, R., (2004). Building New Management Theory by Integrating Processes and Products of Thought: Essay, Journal of Management Enquiry, March 2004, pp. 34 - 47.

91. Miller, D. T. (1999). The norm of self interest, American Psychologist, 54 (12), pp 1053 - 1060.

92. Mintzberg, Henry. (1973). The nature of managerial work, New York: Harper \& Row.

93. Mintzberg, Henry. (2004). Managers not MBAs: A Hard Look at the soft practice of Managing and Management Development. San Francisco: B K Publishers, Inc.

94. Minuora, T. (2002). Address to the world class manufacturing forum.

95. Mirvis, P. H. (1997). "Soul Work" in Organizations. Organization Science, 8, pp. 193 - 206.

96. Mitchell, L. (2001), Corporate Irresponsibility, Yale University Press, New Haven, CT.

97. Morrison, A. M., White, R. P., \& Van Velsor, E. (1987), Breaking the glass ceiling, Reading, MA: Addison - Wesley.

98. Myers, I. and McCaulley, M. (1990), Manual: A Guide to the Development and the Use of the MyersBriggs Type Indicator, Consulting Psychologists Press, Palo Alto, CA.

99. Ohno, T. (1988).Toyota Production System, Productivity Press, Portland, OR.

100. Pandit, V. (2009). Foreword. In Bhaskar, R. Kumar. (2009). Man Management: A Values Based Management Perspective - Based on the Discourses of Bhagavan Sri SathyaSai Baba, School of Business Management, Accounting and Finance, Sri Sathya Sai University, Sri Sathya Sai Vidyagiri, Prasanthi Nilayam 515134, Anantapur District, Andhra Pradesh.

101. Penrose, E. T. (1959). The theory of the growth of the firm, Cambridge, M. A.: Blackwell.

102. Pfeffer, J. (2001). Business and the Spirit: Management Practices that sustain values; Research Paper No. 1713, Graduate School of Business, Stanford University, Stanford, CA, October 2001. 
103. Pfeffer, J. and Baron, J. N. (1988). Taking the workers back out: Recent trends in the structuring of employment. In B. M. Straw and L. L. Cumings (Eds.), Research in Organizational Behavior, Vol. 10, Greenwich, C T: JAI Press, pp. $257-303$.

104. Pfeffer, J. and Sutton, R. I. (2000). The Knowing - Doing Gap: How smart Companies Turn Knowledge Into Action. Boston: Harvard Business School Press.

105. Pillutla, M. \& Murnighan, J. K. (1996). Unfairness, anger, and spite: Emotional rejections of ultimatum offers. Organizational Behavior and Human Decision Processes, 68, pp. 208 - 224.

106. Rand, A. (1957). Atlas Shrugged, New York: Random House.

107. Rasch, R., Shen, W., Davies, S.E., \& Bono, J. (2008, April). The development of a taxonomy of ineffective leadership behaviors. Paper presented at the $23^{\text {rd }}$ annual Conference of the Society for Industrial and Organizational Psychology, San Francisco, CA.

108. Rao, U.S. (2009). Dean's Message. In Bhaskar, R. Kumar. (2009). Man Management: A Values Based Management Perspective - Based on the Discourses of Bhagavan Sri SathyaSai Baba, School of Business Management, Accounting and Finance, Sri Sathya Sai University, Sri Sathya Sai Vidyagiri, Prasanthi Nilayam 515134, Anantapur District, Andhra Pradesh.

109. Roberts, C. and McDonald, G. (1995). Training to fail. Journal of Management Development. 14(4), pp. 16-31.

110. Rother, M. and Shook, J. (1999). Learning to See, Lean Enterprise Institute, Brookline, MA.

111. Sanghi, Seema. (2002). Ethical Issues at Work: A Comparative Study between U K and Indian Managers Research Paper, Vikalpa: The Journal for Decision Makers. [A Research Journal of Indian Institute of Management, Ahmedabad, India], 27 (1), pp. 21 - 33.

112. Schmidt, J. \& Lines, S. (2002). A measure of success. People Management, 8(9), pp. 32.

113. Schuler, R. S. (1998). Human Resource Management, In M. Poole \& M. Warner (Eds.), The handbook of human resource management, London: International Thomson Business Press.

114. Schur, J. B. (1991). The overworked American. New York: Basic Books.

115. Schwartz, B. (1997). Psychology, idea psychology, and ideology, Psychological Science, 8(1) pp. 21 - 27.

116. Senge, P. (2000). The puzzles and paradoxes of how living companies create wealth in Beer, M. and Nohira, N. (Eds.), Breaking the Code of Change, Harvard Business School Press, Boston, MA, pp. 59 - 81.

117. Service, B. and Arnott, D. (2006). LCC The Leadership Quotient: 12 Dimensions for Measuring and Improving Leadership, New York: Universe.

118. Service, R. W. (2010). Management: "is" versus "should be". Problems and Perspectives in Management, 8 (2), pp. $21-34$.

119. Service, R. W. and Lockmay, A. III. (2008). Managerial Promotions Formulas and a Human Resource Management Model, Management Research News, 31(4) pp. 245 - 257.

120. Shim, D. S. (2001). Recent human resources development in OECD member countries. Public Personnel Management, 30(3), pp. 323.

121. Simon, H. A. (1957). Models of Man, New York: John Wiley.

122. Skinner, B. F. (1953). Science and Human Behavior, New York: Macmillan.

123. Smith, S. A. and Mazin, R. A. (2004). The HR Answer Book, New York: AMACOM.

124. Squires, G. (2001). Management as a professional discipline, Journal of Management Studies, 38 (4), pp. 73 89.

125. Storey, J. (1989). Management development: a literature review and implications for future research. Part I: conceptualizations and practices, Personnel Review, 18 (6), pp. 3 - 19.

126. Storey, J. (1990), Management development: a literature review and implications for future research. Part II: profiles and contexts, Personnel Review, 18 (6), pp. 3 - 19.

127. Tobin, J. (2003). To conquer the Air. New York: Free Press.

128. Tsurumi, Y. (2005). Dysfunctional Corporations and flawed business education in America, Japanese Journal of Administrative Science, 18 (3), pp. 179 - 92.

129. Volhardt, C. (2005). Pifzer's prescription for the risk business of executive transitions, Journal of Organizational Excellence, 25(1), pp. 3 - 15.

130. Watkins, M. (2003). The first 90 days, Cambridge, MA: Harvard Business School Press.

131. White, E. (2005). Rethinking quality improvement, The Wall Street Journal, Sept 12, 2005.

132. Witzel, M. (2005). Profits and charity are not mutually exclusive, Financial Times, August 16, 2005.

133. Wong, E. (2001). A stinging office memo boomerangs: Chief Executive is criticized after upbraiding workers by email. New York Times. April 5, 2001. Section C, p.1.

134. Wren, D. A. and Bedeian, A. G. (2009). The Evolution of Management Thought (6 ${ }^{\text {th }}$ edition). Hoboken. N J: John Wiley \& Sons. 